\title{
Genetic and Non-Genetic Factors on Productive and Reproductive Performance of Indigenous Buffalo
}

\author{
Uddhav Paneru ${ }^{1 @}$, Keshav Prasad Dhungana $^{1}$, Surendra Kanu ${ }^{2}$ and Parbati Sharma ${ }^{3}$ \\ ${ }^{1}$ Directorate of Agricultural Research (Gandaki Province), Lumle, Kaski, Nepal@: pnruddhav.npl@gmail.com. \\ (iD) https://orcid.org/0000-0003-1788-6269, KPD; dhunganakeshab1@ gmail.com \\ ${ }^{2}$ Institute of Agriculture and Animal Science (IAAS), Paklihawa, Tribhuvan University, Nepal; \\ drsurendra2065@gmail.com \\ ${ }^{3}$ National Livestock Resource Management and Promotion Office, Lalitpur, Nepal; \\ vet.parwati2016@gmail.com
}

Received 3 Nov 2020, Revised 20 March 2021, Accepted 25 April 2021, Published 30 April 2021

Scientific Editors: Nirajan Bhattarai, Saroj Sapkota, Neena Gorkhali

Copyright (C) 2021 NARC. Permits unrestricted use, distribution and reproduction in any medium provided the original work is properly cited.

The authors declare that there is no conflict of interest.

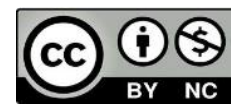

OPEN ACCESS

Licensed under the Creative Commons Attribution NonCommercial 4.0 International (CC BY-NC 4.0)

\section{ABSTRACT}

Indigenous buffalo is the black gold of Nepal because of its important contribution to the livelihood of the rural farmers and agricultural economy of the country. A study was done to investigate the performance of indigenous buffalo found in high-hill of the western districts of Nepal. Further, effect of genetic and nongenetic factors on productive and reproductive performance of indigenous buffalo was accessed. This study was done in four districts: Myagdi, Baglung, Parbat and Kaski for 2 consecutive years from 2016 to 2017. A semi-structured and questionnaire survey format was prepared and was filled with verbal answers from 142 farmers on a different aspect of buffalo farming. Further, recording formats were distributed to enumerators for the recording of different information that cannot be collected from the survey. Total of 201 indigenous buffaloes (132 Lime and 69 Parkote) and minimum of 25 buffaloes in each site were measured for determining productive and reproductive performance. Further, 65 collected milk samples were subjected to Animal Nutrition Laboratory of DoAR, Lumle for determination of milk composition. Results of the findings revealed that there was a high variation in productive and reproductive performance of indigenous buffalo. Lactation milk yield of Lime buffalo was observed slightly higher $(1180.90 \pm 27.94 \mathrm{~L})$ than Parkote buffalo $(1170.56 \pm 42.29 \mathrm{~L})$ but was non-significant $(\mathrm{p}>0.05)$. Lactation yield of indigenous buffalo in Ramja, Parbat $(1254.73 \pm 38.43 \mathrm{~L})$ was observed significantly higher $(\mathrm{P}<0.002)$ than other research locations. Genetic evaluation of indigenous buffaloes and selection of better performers help in increasing productivity and lead to conservation by competitive advantage of indigenous buffaloes. Non-genetic factors play an important role in the productive and reproductive performance of indigenous buffalo and need to account for these effects to select buffalo for its genetic merit.

Keywords: Non-genetic factors, Productive, Reproductive, Lactation Milk Yield

\section{सारांश}

स्थानिय भैंसीले ग्रामिण कृषकहरुको जीविकोपार्जन र देशकोअर्थतन्त्रमा महत्तोपुर्ण भूमिका खेल्दछ त्यसैले यो नेपालको कालो सुनहो। स्थानिय भैंसीको उत्पादन पत्तालगाउने उदेश्यले पश्चिम नेपालको उच्च पहाडमा एउटा अनुसन्धान गरियो।येससँगै आनुवांशिक र अरु वातावरणीय तत्तोहरुले भैंसीको उत्पादन र प्रजननमा पार्ने असरहरुकोअनुसन्धान गरियो।योअनुसन्धान चार पहाडी जिल्लाहरु म्याग्दी, बाग्लुंग ,पर्बत र कास्कीमा लगातार दुई बर्ष इ.स. २०१६-२०१७ सालमा गरिएको थियो।अर्धसंरचित घरधुरी सर्वेक्षण फारम तयार गरियो र १४२ जना कृषकहरुले मौखिक भत्तुभएका कुराहरुले फारम भरियो। घरधुरी सेर्बेक्षणबाट संकलन गर्न कठिन कुराहरु रिपोर्ट गर्नको लागी पशु उत्पादन फारम तयार गरियो र गणनाकर्तालाई हस्तान्तरण गरियो। भैंसीको उत्पादन र प्रजनन क्षमता पत्ता लगाउन २०१ भैंसीहरु ( १३२ लिमे र ६९ पारकोटे ) र प्रत्येक क्षेत्रमा कम्तिमा २५ भैंसीहरुको मापन गरियो। दुधको संरचना पत्ता लगाउन थप ६५ वटा दुधका नमुनाहरु भैंसीको पशुआहार प्रयोगशाला, लुम्लेमा लिएर आइयो। अनुसन्धानबाट स्थानिय भैंसीको उत्पादन र प्रजनन क्षमतामा धैरे नै फरक रहेको पाइयो। लिमे भैंसीको पर्तिबेत दुध उत्पादन (१२८०. ९० \pm २७.९४लि.), पारकोटे भैंसीको भन्दा धेरै (१२७०.४६ \pm ४२.२९लि.) पाइयो तर तथ्यांक शास्त्रको आधारमा भित्र नभएको (सम्भावना >0.००५) पाइयो। भैंसीको पर्तिबेत दूध उत्पादन राम्जा पर्बतमा अरु ठाउँको 


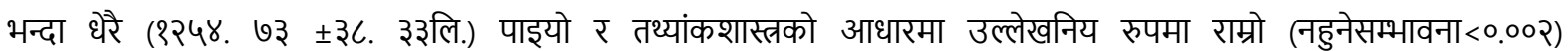
पाइयो।आनुवांशिकको आधारमा राम्रो उत्पादन दिने भैंसीको छनोट गरेमा भेंसीको उत्पदकत्तो बिर्दी भई स्थानिय भेंसी पनि दुध उत्पादनमा पर्तिस्पर्धि हुनेछ र स्थानिय भैंसीको संरक्षण हुने देखिन्छ। विभिन्न वातावरणीय तत्तोहरुले समेत स्थानिय भैंसीको उत्पादन र प्रजनन क्षमतामा फरक पार्ने हुँदा स्थानिय भैंसीको छनोट गर्दा ति तत्तोहरुलाई मध्येनजर गरेमा आनुवांशिकतमा उत्कृस्ट भैंसी छनोट गर्न सकिन्छ।

\section{INTRODUCTION}

Buffalo is a major livestock commodity among 35 livestock species (Joshi et al 2020) in Nepal where buffalo population in-country is estimated to be 5.30 million (MLD, 2018/19). Buffalo is an important livestock commodity of Nepal, it alone contributes about $63 \%$ and $52 \%$ of national annual milk and meat production respectively (MoALD, 2018/19). It is believed that nearly half of the households of the country keep buffaloes primarily for milk, meat, manure, skin, traction and ploughing agricultural land. Most of the Nepalese people have preferred buffalo milk to cattle milk due to its appealing white color and richness in fat and solid not fat which has a good taste and fetches a higher price in the market. In addition, people from a remote area of the country want to keep buffaloes more than cattle for milking because buffalo milk can be profitable even by making ghee. Native buffalo of a country can be broadly classified into three groups based on their breed characteristics: Lime, Parkote and Gaddi. These breeds are hilly buffalo and reared by the farmers of the mid and high hills region of Nepal above $1000 \mathrm{~m}$ asl. Lime and Parkote buffaloes have been characterized to the extent of being phenotypically recognizable and are abundantly found in the western mid-hills of Nepal. Among the existing buffalo population, indigenous buffalo and their intermediate types contribute around 64\% (Neupane et al 2007). Paudel (2017) also reported that there are more than $65 \%$ of local buffalo in Nepal.

The pure breed Lime is believed to have originated from wild Arna (Bubalus arnii) and has been domesticated throughout the known history of Nepal (Rasali, 1998). These buffaloes can be found more towards the higher altitude; mid-hills and high in the country. It has been estimated that about $35 \%$ of the total indigenous buffalo population in the hills and mountains of the country are Lime and only $25 \%$ of these are Parkote (Shrestha et al 2003, Rasali 1998, Rasali, 2000). Parkote buffalo are more common in the mid-hill and river valleys of Nepal. There is limited genetic improvement program in indigenous buffalo to increase the production and productivity of these buffaloes. Further, farmers are practicing rampant crossbreeding with Murrah to increase the production and productivity of these animals thus resulting decrease in pure breed in the hills and mountains. Similarly, genetic effect such as breed effect and non-genetic factors such as location, parity and year play an important role in the productive and reproductive performance of buffalo and should be taken into account to select the best animal for its genetic merit. Therefore, this study aims to access the productive and reproductive performance of indigenous buffalo in farmer's managed condition in the mid-hills of western region of Nepal. Further, we examined the effects of different genetic and non-genetic factors on the productive and reproductive performance of the buffalo.

\section{MATERIALS AND METHODS}

\section{Selection of site and farmers}

In close collaboration with respective District livestock Service Offices of selected location, four sites: Ramche of Myagdi district, Tarakhola of Baglung district, Ramja, Deurali of Parbat district and Lwang Ghalel of Kaski district were considered for study during consecutive years from 2016 to 2017. These sites were also considered as conservation sites of indigenous buffalo by District Livestock Service Offices (DLSO) of the respective district. All sites fall in the high hill region: 1400 - $2100 \mathrm{~m}$ asl of Nepal, which is the most prominent production system for indigenous buffalo.

\section{Production system information}

A semi-structured and open-ended questionnaire survey format was developed and was verbally asked to a total of 142 farmers from four districts. Further, those farmers who have been rearing at least one indigenous milking buffalo and who agree to comply as per protocol: agree to help recorder in keeping fortnightly milk record, keeping milk sample at regular interval and maintaining reproductive records, were selected for the study. We could not record milk production performance from all the farmers because of 
one or more difficulties faced in each site. Total number of farmers in each location is presented in Table 1 .

Table 1. Total number of household considered in a survey

\begin{tabular}{lll}
\hline Location & Altitude (m asl) & Total households \\
\hline Ramche of Myagdi & 1,800 & 31 \\
\hline Tarakhola of Baglung & 2,100 & 39 \\
\hline Ramja, Deurali of Parbat & 1,500 & 40 \\
\hline Lwang Ghalel of Kaski & 1,600 & 32 \\
\hline
\end{tabular}

Production and reproduction performance

Minimum of 25 buffaloes in each site was used for recording the production and reproductive performance (Table 2). Only those buffaloes which were calved after the commencement of research, were considered for recording.

Table 2. Number of buffaloes considered for recording productive and reproductive performance

\begin{tabular}{llll}
\hline Location & Lime & Parkote & Total \\
\hline Myagdi & $9(7)$ & $18(9)$ & 43 \\
\hline Baglung & $21(14)$ & $7(6)$ & 48 \\
\hline Parbat & $39(21)$ & $11(2)$ & 73 \\
\hline Kaski & $12(9)$ & $9(7)$ & 37 \\
\hline Total & 132 & 69 & 201
\end{tabular}

Note: Number in parenthesis indicates number of recording taken in the second year

\section{Milk production performance}

A recording format was developed and enumerators were trained to keep records of production and reproduction performance. We provided a uniform milk recording jug to all enumerators for recording the productive performance of buffalo at fortnightly intervals also called test day milk yield. Milk was measured after 15 minutes of milking to allow enough time to settle the milk bubbles to minimize error during recording. First fortnightly milk recording was done after 15 days of calving in the morning and evening and successive milk recordings were followed thereafter. Some extra days of milk after earlier recording were not counted if we cannot take the next test day record, and that record was considered as the last test day record. Further, if farmers practice providing milk to buffalo calf directly from the teat, then extra milk from that teat was also added in that particular test day record. Finally, we multiply the total number of test days recordings by 15 to get lactation milk yield (LMY).

\section{Millk composition}

A total of 65 representative milk samples containing 28 samples from Lime and 37 milk samples from Parkote buffalo were collected from the aforementioned sites. Milk samples were collected by thoroughly stirring a milking can after milking of buffalo. Milk samples were then used to determine percentage fat, protein, and solids not fat (SNF) using Lactoscan milk analyzer (MilkAnalyzer, www.mikotonic.com, serial No 11-16,4245, Bulgaria). Milk traits considered in the study were as mentioned in Table 3.

Table 3. Milk traits considered in this study

\begin{tabular}{ll}
\hline LMY & Lactation milk yield (305 days) \\
\hline SNF & Solid, Not Fat \\
\hline Fat $\%$ & Percentage of fat in the milk \\
\hline Protein $\%$ & Percentage of protein \\
\hline AFS & Age at first service of the female \\
\hline AFC & Age at first calving \\
\hline CI & The interval between successive calving \\
\hline
\end{tabular}




\section{Data analysis}

Collected data were entered in Microsoft excel and analyzed by maximum likelihood using the animal model from R software. The linear model used for the study on different productive traits are;

$$
Y_{i j k l m}=\alpha_{i}+\beta_{j}+\gamma_{k}+\delta_{l}+e_{i j k l m}
$$

Where, $\mathrm{Y}_{\mathrm{ijklm}}=$ Effect of $\mathrm{m}^{\text {ih }}$ observation on $\mathrm{i}^{\text {th }}$ breed, $\mathrm{j}^{\text {th }}$ location, $\mathrm{k}^{\text {th }}$ parityand $\mathrm{l}^{\text {th }}$ year

$\mu=$ General mean

$\alpha_{\mathrm{i}}=$ Effect of $\mathrm{i}^{\text {th }}$ breed

$\beta_{\mathrm{j}}=$ Effect of $\mathrm{j}^{\text {th }}$ location

$\gamma_{\mathrm{k}}=$ Effect of $\mathrm{k}^{\text {th }}$ parity

$\delta_{1}=$ Effect of $1^{\text {th }}$ year

$\mathrm{e}_{\mathrm{ijk} k \mathrm{~m}}=$ random error assumed to be normally distributed with 0 means and common variance $\sigma^{2}$.

\section{RESULTS}

\section{Brief description of farmers managed production system}

This system consists of keeping at least one buffalo up to 5 buffaloes in the majority of the household and raising these animals by family members. This is low input and low output production system; farmers fed their animals by using traditional feedstuffs like rice/millet straw, cooked homemade concentrate (Kundo) and different fodder species, and return from animals are also low to medium due to lack of adequate nutrients all-round the year. Further, some farmers practice keeping their animals in the nearby jungle during the dry period of the animals to reduce the cost of feed and save time to take care of their animals. Breeding of the animals takes place mostly by natural mating using buffalo bull available in the vicinity. This is a subsistence livestock production system prevalent in the high hills region of Nepal to get enough nutrients from animal sources and get an extra source of income to support the family.

\section{Production performance of indigenous buffaloes}

The productive performance of indigenous buffaloes is presented in Table 4. It was observed that the lactation milk yield of Lime buffalo was higher $1180.90 \pm 27.94 \mathrm{~L}$ than Parkote buffalo $1170.56 \pm 42.29$ $\mathrm{L}$, but the effect of breed on lactation milk yield (LMY) was non-significant ( $\mathrm{p}>0.05)$. Further, the result showed that the lactation milk yield of buffalo in Ramja, Parbat was higher $1254.73 \pm 38.43 \mathrm{~L}$ than other locations, and was significantly different $(\mathrm{p}<0.002)$ than other locations. Moreover, the result showed that milk production of indigenous buffalo was the highest in $3^{\text {rd }}$ and $4^{\text {th }}$ parity and decrease after $4^{\text {th }}$ parity; but the effect of parity on lactation milk yield was non-significant ( $>>0.05$ ). The reason behind the non-significant effect of parity on lactation milk yield could be due to less observation in the latter part of lactation hindered estimation of correct means. The result of the finding was in agreement with other findings that the milk yield of indigenous buffalo decrease after $4^{\text {th }}$ parity (Shrestha et al 2005).

Table 4. Effect of genetic and non-genetic factors on the productive performance of indigenous buffalo

\begin{tabular}{|c|c|c|c|c|}
\hline Parameters & $\begin{array}{l}\text { No. of } \\
\text { Observations }\end{array}$ & $\begin{array}{l}\text { Milk yield (L) } \\
\pm \mathrm{SE}\end{array}$ & Minimum & Maximum \\
\hline \multicolumn{5}{|l|}{ Breed } \\
\hline Lime & 132 & $1180.90 \pm 27.94$ & 497.15 & 2063.83 \\
\hline Parkote & 69 & $1170.56 \pm 42.29$ & 362.61 & 1972.33 \\
\hline P-value & & 0.615 & & \\
\hline \multicolumn{5}{|l|}{ Location } \\
\hline Ramche, Myagdi & 43 & $1206.33 \pm 60.99$ & 472.47 & 1972.33 \\
\hline Tarakhola, Baglung & 48 & $1194.37 \pm 41.44$ & 457.57 & 1952.0 \\
\hline Ramja, Parbat & 73 & $1254.73 \pm 38.43$ & 636.14 & 2063.83 \\
\hline Lwang Ghalel, Kaski & 37 & $868.93 \pm 48.29$ & 362.61 & 1695.29 \\
\hline P-value & & 0.002 & & \\
\hline \multicolumn{5}{|l|}{ Year } \\
\hline 2016 & 126 & $1215.27 \pm 25.24$ & 2063.83 & 362.61 \\
\hline 2017 & 75 & $1113.56 \pm 27.51$ & 1695.44 & 379.55 \\
\hline P-Value & & 0.0384 & & \\
\hline
\end{tabular}




\begin{tabular}{|c|c|c|c|c|}
\hline Parameters & $\begin{array}{l}\text { No. of } \\
\text { Observations }\end{array}$ & $\begin{array}{l}\text { Milk yield (L) } \\
\pm \mathrm{SE}\end{array}$ & Minimum & Maximum \\
\hline \multicolumn{5}{|l|}{ Parity } \\
\hline 1 & 24 & $1045.31 \pm 83.63$ & 379.56 & 1851.79 \\
\hline 2 & 41 & $1163.74 \pm 52.03$ & 362.61 & 2063.83 \\
\hline 3 & 36 & $1235.37 \pm 55.80$ & 550.02 & 2063.83 \\
\hline 4 & 24 & $1269.99 \pm 78.29$ & 472.47 & 1972.33 \\
\hline 5 & 28 & $1222.65 \pm 61.64$ & 615.92 & 1952.00 \\
\hline 6 & 20 & $1122.72 \pm 61.41$ & 751.32 & 1662.25 \\
\hline 7 & 8 & $1258.46 \pm 65.62$ & 950.52 & 1525.39 \\
\hline 8 & 8 & $1152.77 \pm 114.97$ & 705.57 & 1695.29 \\
\hline 9 & 6 & $925.95 \pm 130.62$ & 457.50 & 1298.43 \\
\hline P-value & & 0.569 & & \\
\hline AIC & 1830 & $\mathrm{BIC}$ & 1846 & \\
\hline Log-likelihood & -909 & & & \\
\hline
\end{tabular}

We observed that indigenous buffalo produce high milk production from October to February (Figure 1). This can be explained by the fact that most of the buffalo calved by November and give high milk production for 5 months from the onset of their lactation. Further, green forage and fodder are available up to February in most of the farmer's household and production of the buffalo decreases in the absence of green forage and fodder. We didn't observe the practice of making silage for feeding their buffalo in the lean season in the survey household and most of the farmers provide very little concentrate for their animals. This also explains the fact that the lower productivity of buffalo after February is not only genetic but also the impact of feed scarcity.

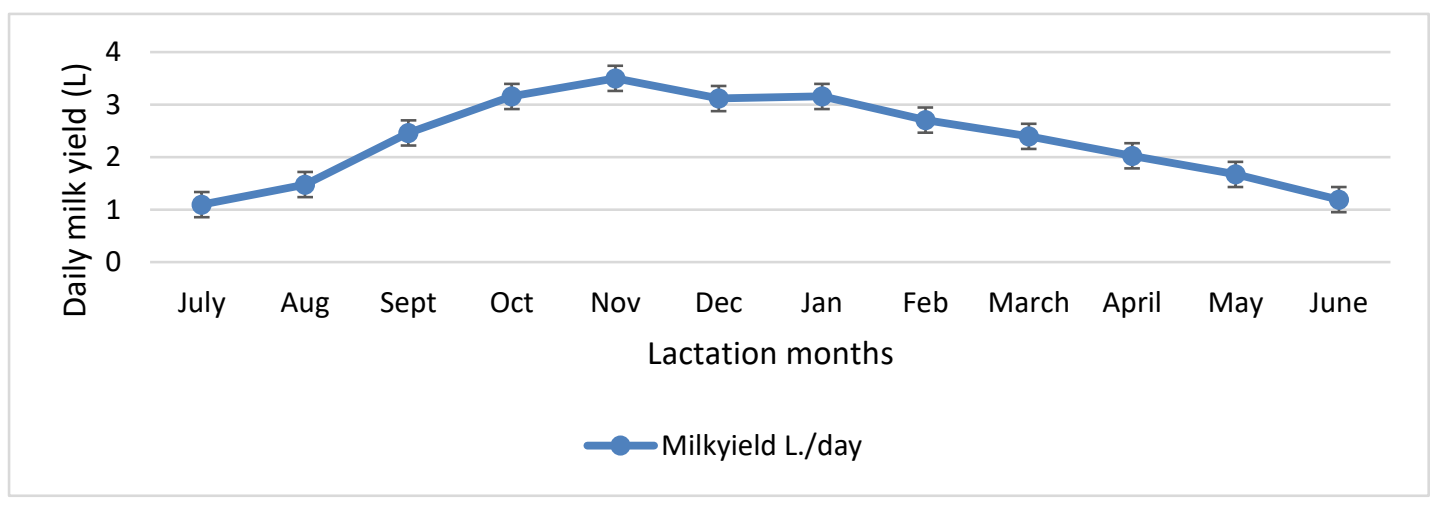

Figure 1. Peak milk yield of indigenous buffalo

Lactation length of indigenous buffalo

The average lactation length of indigenous buffalo was observed 9.87 months, but the effect of breed on lactation length was non-significant (Table 5).

Table 5. Effect of non-genetic factors on lactation length of indigenous buffalo

\begin{tabular}{lll}
\hline Parameters & No. of observations & Lactation length (months \pm SE) \\
\hline Breed & & \\
\hline Lime & 65 & $9.90 \pm 0.28$ \\
\hline Parkote & 58 & $9.82 \pm 0.38$ \\
\hline P-value & & 0.865 \\
\hline Location & & \\
\hline Ramche,Myagdi & 43 & $10.15 \pm 0.41$ \\
\hline Tarakhola,Baglung & 48 & $9.57 \pm 0.21$ \\
\hline Ramja,Parbat & 73 & $8.83 \pm 0.40$ \\
\hline LwangGhalel, Kaski & 37 & $10.23 \pm 0.88$ \\
\hline p-value & & 0.865 \\
\hline
\end{tabular}


Reproductive performance of Indigenous buffalo

The reproductive performance of indigenous buffaloes across breeds is presented in Table 6. It was observed that the average age at first service, age at first calving, and calving interval of indigenous buffalo were 3.15 years, 4.15 years and 13.94 months respectively and was non-significant across breeds.

Table 6. Reproductive performance of indigenous buffaloes across breeds

\begin{tabular}{|c|c|c|c|c|c|c|}
\hline \multirow[t]{2}{*}{ Traits } & \multicolumn{2}{|c|}{ No. of Observation } & \multirow{2}{*}{$\begin{array}{l}\text { Lime } \\
\text { Mean } \pm S E\end{array}$} & \multirow{2}{*}{$\begin{array}{l}\text { Parkote } \\
\text { Mean } \pm \text { SE }\end{array}$} & \multirow{2}{*}{$\begin{array}{l}\text { Total } \\
\text { Mean } \pm \text { SE }\end{array}$} & \multirow[t]{2}{*}{ P-Value } \\
\hline & Lime & Parkote & & & & \\
\hline Age at $1^{\text {st }}$ Service (Year) & 104 & 72 & $3.15 \pm 0.07$ & $3.14 \pm 0.08$ & $3.15 \pm 0.05$ & 0.915 \\
\hline Age at $1^{\text {st }}$ Calving (Year) & 104 & 72 & $4.14 \pm 0.07$ & $4.15 \pm 0.08$ & $4.14 \pm 0.05$ & 0.865 \\
\hline Calving Interval (Month) & 87 & 53 & $14.00 \pm 0.34$ & $13.83 \pm 0.37$ & $13.94 \pm 0.25$ & 0.737 \\
\hline
\end{tabular}

The reproductive performance of indigenous buffaloes across different locations is presented in Table 7. It was observed that age at first service, age at first calving and calving interval of buffalo in Parbat district was $2.92 \pm 0.08$ years, $3.90 \pm 0.08$ years and $12.97 \pm 0.39$ months and was significantly better $(<0.001)$ than other locations.

Table 7. Reproductive performance of indigenous buffaloes across different locations

\begin{tabular}{llllllll}
\multicolumn{2}{l}{ Table 7. Reproductive performance of indigenous buffaloes across different locations } \\
\hline $\begin{array}{l}\text { Location/Repr } \\
\text { oductive traits }\end{array}$ & $\begin{array}{l}\text { No. of } \\
\text { Obs. }\end{array}$ & $\begin{array}{l}\text { Baglung } \\
\text { Mean } \pm \text { SE }\end{array}$ & $\begin{array}{l}\text { Myagdi } \\
\text { Mean } \pm \text { SE }\end{array}$ & $\begin{array}{l}\text { Parbat } \\
\text { Mean } \pm \text { SE }\end{array}$ & $\begin{array}{l}\text { Kaski } \\
\text { Mean } \pm \text { SE }\end{array}$ & $\begin{array}{l}\text { Total } \\
\text { Mean } \pm \text { SE }\end{array}$ & $\begin{array}{l}\text { P- } \\
\text { Value }\end{array}$ \\
\hline $\begin{array}{l}\text { Age at } 1^{\text {st }} \\
\text { service (year) }\end{array}$ & 176 & $3.61 \pm 0.07$ & $2.85 \pm 0.10$ & $2.92 \pm 0.08$ & $3.13 \pm 0.17$ & $3.15 \pm 0.05$ & $<0.001$ \\
\hline $\begin{array}{l}\text { Age at } 1^{\text {st }} \\
\text { calving (year) }\end{array}$ & 176 & $4.62 \pm 0.70$ & $3.84 \pm 0.10$ & $3.90 \pm 0.08$ & $4.14 \pm 0.17$ & $4.14 \pm 0.54$ & $<0.001$ \\
\hline $\begin{array}{l}\text { Calving Interval } \\
\text { (month) }\end{array}$ & 140 & $14.40 \pm 0.37$ & $13.67 \pm 0.47$ & $12.97 \pm 0.39$ & $15.48 \pm 0.92$ & $13.93 \pm 0.25$ & 0.007 \\
\hline
\end{tabular}

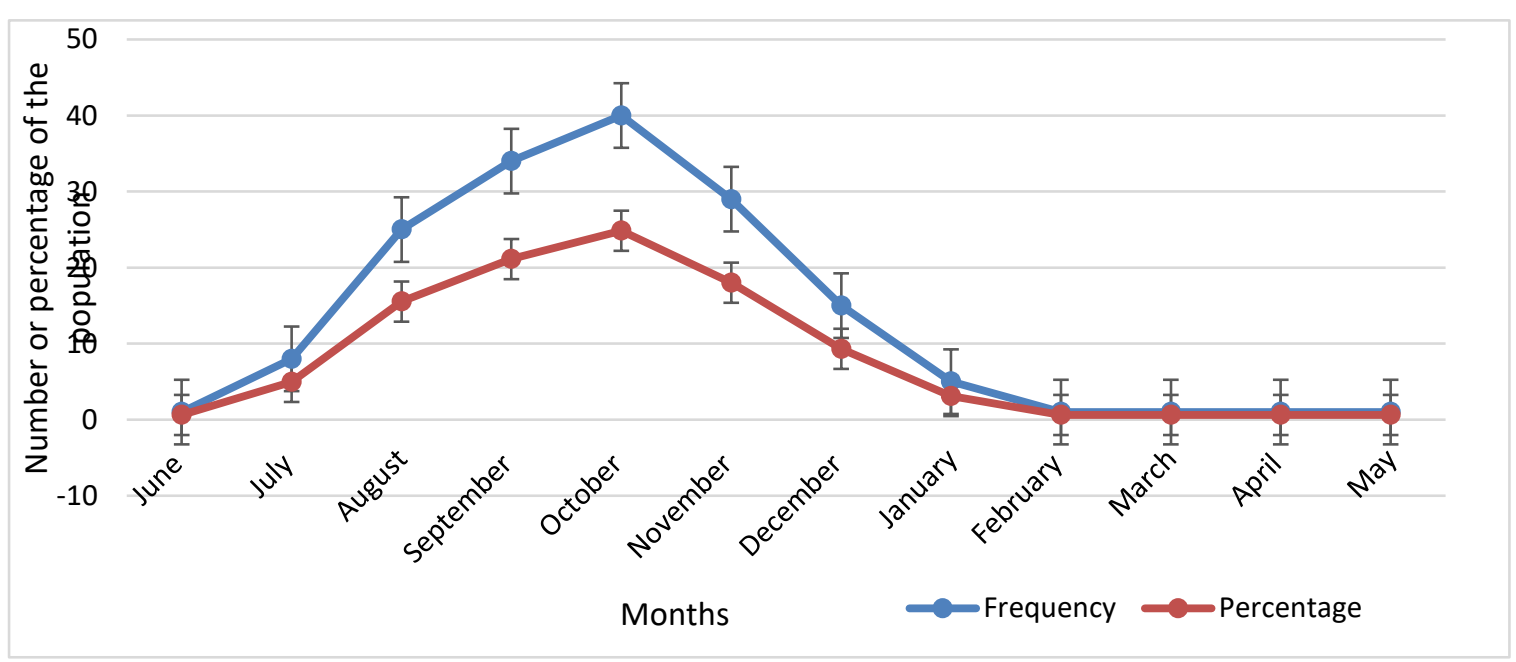

Figure 2. Calving month of indigenous buffalo

It was observed that buffalo are seasonal breeders as most of the indigenous buffalo calved from July month to December month (Figure 2). There are many reasons behind the seasonal breeding of the buffalo, one of the reasons is availability of green forage and fodder during the rainy season. Further, low cholesterol level was observed in buffalo during stress period (Shah et al., 2017), which affect the biosynthesis of steroid hormone and ovarian functional activity (Doisy 1972).

Milk composition of indigenous buffalo

It was observed that the milk composition of indigenous buffaloes was enriched with high fat, Solid not fat (SNF), lactose, and protein content (Table 8). We observed a very high-fat content of indigenous buffalo than Murrah and other cross-breed buffalo found in other studies (Ref). 
Table 8. Breed-wise milk composition of indigenous buffalo

\begin{tabular}{llllll}
\hline Breed & No. of Obs. & Fat & SNF & Lactose & Protein \\
\hline Lime & 28 & $8.73 \pm 0.31$ & $8.17 \pm 0.40$ & $3.39 \pm 0.07$ & $3.42 \pm 0.07$ \\
\hline Parkote & 37 & $8.39 \pm 0.49$ & $7.78 \pm 0.25$ & $3.44 \pm 0.11$ & $3.46 \pm 0.11$ \\
\hline Total & 65 & $8.54 \pm 0.31$ & $7.93 \pm 0.22$ & $3.42 \pm 0.07$ & $3.44 \pm 0.07$ \\
\hline P-Value & & 0.599 & 0.348 & 0.744 & 0.791 \\
\hline
\end{tabular}

It was observed that buffaloes from Baglung districts have high fat and SNF content, 9.36 \pm 0.59 and $8.04 \pm 0.22$ respectively but the milk composition across districts was non-significant (Table9).

\begin{tabular}{llllll}
\multicolumn{2}{l}{ Table 9. Location-wise milk composition of indigenous buffalo } & & \\
Location & $\begin{array}{l}\text { No. of } \\
\text { Obs. }\end{array}$ & Fat & SNF & Lactose & Protein \\
\hline Myagdi & 19 & $7.96 \pm 0.56$ & $7.78 \pm 0.29$ & $3.40 \pm 0.12$ & $3.47 \pm 0.14$ \\
\hline Baglung & 20 & $9.36 \pm 0.59$ & $8.04 \pm 0.22$ & $3.59 \pm 0.11$ & $3.53 \pm 0.10$ \\
\hline Parbat & 14 & $7.76 \pm 0.49$ & $7.32 \pm 0.25$ & $3.26 \pm 0.11$ & $3.35 \pm 0.13$ \\
\hline Kaski & 12 & $9.01 \pm 0.80$ & $8.70 \pm 0.99$ & $3.33 \pm 0.2$ & $3.36 \pm 22$ \\
\hline Total & 65 & $8.54 \pm 0.31$ & $7.93 \pm 0.22$ & $3.41 \pm 0.07$ & $3.44 \pm 0.07$ \\
\hline P-value & & 0.172 & 0.256 & 0.361 & 0.760 \\
\hline
\end{tabular}

\section{DISCUSSION}

We observed a high variation in lactation milk yield (362.61-2063.83 L) for both Lime and Parkote buffalo, which indicates that there is a high potential for genetic improvement through selection within the breeds. Therefore, there is no need to cross-breed these animals to increase production performance for short-term benefit. Further, both breeds have similar productive performance and there is no benefit of selecting one breed over another. Rasali (1998) observed a similar finding for average milk production of $995 \mathrm{~L}$. of indigenous buffalo in the western hills of Nepal. A similar finding was also observed by (Joshi et al 1992). Shrestha et al (2005) also observed the milk yield of indigenous buffalo Lime, Parkote and Murrah cross 961.7 L, 1022 L, 1073 L respectively in western hills from 2001-2003 in his study in six hilly districts of Nepal. Paudel (2017) observed a higher lactation milk yield of $1615 \pm 205 \mathrm{~L}$ for Lime and $1800 \pm 215 \mathrm{~L}$ for Parkote buffalo in northern Arghakhanchi under improved production system. These higher results might be due to higher temperatures and good management in Arghakhanchi than in the current research sites. In high hills, fodder is mostly available in the summer and autumn season and animals are fed with mostly dry roughages in the winter season whereas in midhills duration of forage and fodder availability is higher.

Different non-genetic factors such as location, year and parity play an important role in the productive and reproductive performance of indigenous buffalo and these factors need to be accounted for the selection and improvement of indigenous buffalo for its genetic merit. High milk production of indigenous buffalo in Ramja, Parbat can be justified by the fact that Ramja, Parbat is warmer than other locations and most of the energy animals obtain from the feed was utilized in milk production while in other locations energy produced from feed was also utilized in the generation of heat to keep their body warm. Shrestha et al (2005) also observed that Lime, Parkote and Murrah cross produced 961.7, 1022, 1073 liters lactation milk yield respectively in the western hills from 2001-2003. Rasali (1996) also reported significant variation in the milk yield of indigenous buffalo in different agro-ecological sites. Amatya et al (2000) observed better lactation performance of buffaloes in the river basins compared to those in the mid and high hills. Effect of the year on lactation milk yield was also observed significant $(\mathrm{p}<0.0384)$ with higher milk production in 2016 than in 2017. Lactation length of indigenous buffalo was observed reasonable and corresponds with the finding from the previous authors (Shrestha et al 2003). Reason behind the non-significant effect of locations on lactation length could be due to the selection of similar locations of high hill regions in all four sites and feed availability in all locations was also nearly similar. Result from current research contradicts the finding from (Shrestha et al 2002), who observed significant effects of location on the lactation length of indigenous buffaloes.

The result indicates that the reproductive performance of indigenous buffalo was also affected by nongenetic factor and need to consider for selection of buffalo. Result from the current study was slightly 
better than the result observed by (Shrestha et al 2003), 4.5 years and 602 days respectively for age at first calving and calving interval for indigenous buffaloes in the mid-hills region of Nepal. Shrestha et al (2003) also observed non-significant effects of breeds on age at first calving. Amatya et al (2000) also observed a slightly higher age at first calving of Parkote buffalo than Lime buffalo the effect of breed on calving interval was non-significant which corresponds to the finding of the current research.

The milk composition of indigenous buffalo was observed much better and farmers can be benefitted by selling both milk and milk products. Shah et al (2016) also observed a similar finding for the milk composition of indigenous buffalo. The reason behind the non-significant effect of locations on milk composition could be due to a few observations taken to investigate the significance of milk composition.

\section{CONCLUSION}

Indigenous buffaloes are important livestock germplasm of Nepal. Further, these animals can survive and produce well in the harsh climate of the mid-hills and high-hills. It was observed that there is a high variation in milk yield, milk composition and reproductive performance of these breeds in farmer's condition. Maximum milk production from these animals was observed more than $2000 \mathrm{~L}$. Average milk production from these animals can be improved by the selection of superior stock. Further, it was observed that different non-genetic factors such as location, year play an important role in the production and productivity of these animals and these factors need to be considered while selecting better animals for breeding purposes.

\section{ACKNOWLEDGEMENTS}

Co-operation obtained from the participatory farmers, officers and technicians of respective DLSO are gratefully acknowledged. Authors are grateful to NARC for the financial support to conduct the research. Authors are also thankful to staff of Animal Husbandry Unit of RARS, Lumle, NARC for implementing the research activities.

\section{REFERENCES}

Agri-Business Promotion and Statistics Division (ABPSD). 2018/019. Statistical information on Nepalese agriculture 2018/2019. Agri-Business Promotion and Statistics Division, Ministry of Agricultural Development, Singdurbar Plaza, Kathmandu.

Joshi BK, NA Gorkhali, N Pradhan, KH Ghimire, TP Gotame, P KC, RP Mainali, A Karkee and RB Paneru. 2020. Agrobiodiversity and its Conservation in Nepal. Journal of Nepal Agricultural Research Council 6: 14-33. DOI: https://doi.org/10.3126/jnarc.v6i0.28111

Neupane SP, NA Gorkhali and PK Pokharel. 2007. Indigenous buffalo of Nepal. Animal Breeding Division. National Animal Science Research Institute. Nepal Agricultural Research Council.

Pradhan SL, Sherchand, L and NP Shrestha. 1996. Policy and strategy for conservation of animal genetic resources in Nepal. Department of Livestock Services, Lalitpur, Nepal.

Rasali, DP. 1996. Effect of altitude, management system and parity on the production performanceof monsoon calving indigenous hill buffaloes under farmers' management in the western hills. LARC Seminar Paper No. 96/28, Kaski, Nepal. Lumle Agriculture Research Center.

Rasali, DP. 1998. Present status of indigenous buffalo genetic resources in the western hills of Nepal. Proceedings of the $4^{\text {th }}$ Global Conference on Conservation of Domestic Animal Genetic Resources. Rare Breeds International, pp. 168-170.

Rasali, DP. 2000. Recent trends in buffalo production in Nepal- a review. Buffalo Newsletter. The FAO InterRegional Cooperative Research Network on Buffalo, Europe-Near East. No 14, pp.6-10.

Rasali, DP, HD Joshi, RK. Patel and AH Harding. 1998a. Phenotypic clusters and karyotypes of indigenous buffaloes in the western hills of Nepal. Lumle Technical Paper No 98/2, Kaski, Nepal. Agriculture Research Station, Lumle.

Rasali,DP, DB Gurung and ER Yadav, 1998b.Performance recording of lactating local and crossbred cows and buffaloes of various exotic blood levels under farmer's management in the western hills, 1995-97, LARC working paper No 98/39.

Shah, MK, Y Hayashi and H Kumagai. 2016. Productive and reproductive performance of indigenous Lime and Parkote buffaloes in the western hills of Nepal. Lifescience Global,5:1. 
Shrestha BS, N Amatya, RM Singh, PK Jha, BR Acharya and KB. Gurung. 2003. Morphological characteristics of indigenous buffaloes in the western hills of Nepal. Final Technical report, HARP, PP-78/00. Nepal Agricultural Research Council. Regional Agricultural Research Station, Lumle.

Shrestha BS, N Amatya, RM Singh, PK Jha, BR Acharya and KB Gurung. 2003. Production performance of indigenous buffaloes in the western hills of Nepal. Final technical report, Development of suitable breeding strategies for indigenous buffaloes in the western hills of Nepal, HARP pp: 78/00. Nepal Agricultural Research Council. Regional Agricultural Research Station, Lumle.

Shrestha BS, LN Paudel,NPOsti,and BK Panta. 2013.Buffalo Genetic Improvement Program in Nepal. Current Status and Future prospects. Buffalo Bulletin, 32 (Special Issue 2): 734-743.

Doisy, RA. 1972. Micronutrient controls on biosynthesis of clotting proteins and cholesterol. In: Hemphill D (ed), Trace Substances in the Environmental Health, 6th edn. University of Missouri Press, Columbia, MO, P. 193.

S Shah, G Gautam, CN Kharel, D Lamsal, Y Pandeya and B Devkota. 2017. Response of novel hormonal protocol in anestrus buffaloes during different breeding seasons. In: Proceeding of the International Buffalo Symposium, Chitwan, Nepal; pp.202-206.

Paudel LN. 2017. Breed improvement through intensive local selection of indigenous buffaloes for food and nutritional security and livelihood improvement in mid-hills of Nepal. In: Proceeding of the International Buffalo Symposium, Chitwan, Nepal; pp. 134. 